\title{
対称的に組成傾斜したアルミナ系高次機能セラミックスの製造と性質
}

\author{
宮本 欽生, 栗 振思, 康燕生, 谷畑 公昭 \\ 大阪大学㢈業科学研究所, $\mathbf{T} 567$ 茨木市美穂 丘8-1.
}

\section{Fabrication and Properties of Alumina-Based Hyperfunctional Ceramics with Symmetrically Compositional Gradient Structures}

\author{
Yoshinari Miyamoto, Zhensi Li, Yan-Sheng Kang and Kimiaki Tanihata \\ The Institute of Scientific and Industrial Research, Osaka University, 8-1 Mihogaoka, Ibaraki 567.
}

Received February 7, 1995

\section{SYNOPSIS}

Hyperfunctional $\mathrm{Al}_{2} \mathrm{O}_{3}$ ceramics with symmetrically graded structures of the $\mathrm{Al}_{2} \mathrm{O} 3 / \mathrm{TiC} /$ $\mathrm{Ni} / \mathrm{TiC} / \mathrm{Al}_{2} \mathrm{O}_{3}$ and $\mathrm{Al}_{2} \mathrm{O}_{3} / \mathrm{Cr}_{3} \mathrm{C}_{2} / \mathrm{Ni}_{2} / \mathrm{Cr}_{3} \mathrm{C}_{2} / \mathrm{Al}_{2} \mathrm{O}_{3}$ were fabricated by SHS/HIP. The SHS/HIP is both a new sintering process of such heterogeneous materials with different sintering tempreratures and a recycling process using a chemical oven of $\mathrm{Si}$ waste in zinc smelting. Strong residual compressive stress of $200 \sim 800 \mathrm{MPa}$ were produced in the outer $\mathrm{Al}_{2} \mathrm{O}_{3}$ layers mainly due to the thermal expansion mismatch between the outer $\mathrm{Al}_{2} \mathrm{O}_{3}$ and inner cermet layers. The compressive stress acted to enhance intrinsic toughness and hardness of $\mathrm{Al}_{2} \mathrm{O}_{3}$. Moreover, the local stress change produced by the surface damage reached to the opposite side through disturbance of the internal stress balance of compression/tension/ compression designed in these materials. This effect is potentially available to give a damage detectable function.

\section{KEY WORDS}

SHS/HIP, $\mathrm{Al}_{2} \mathrm{O}_{3} / \mathrm{TiC} / \mathrm{Ni} / \mathrm{TiC} / \mathrm{Al}_{2} \mathrm{O}_{3}$, symmetrically graded structure, residual compressive stress, hyperfunction.

\section{1 诸言}

セラミックスの勒性や強度を上げるために，粒子分 散やウィスカー，織維との複合化が行われている、し かし両特性を同時に上げるのは難しく，複合化が欠陥 を導入し強度劣化を起こす例も多い，また，均質的な 椱合化では靬性や強度を独立に制御するのは難しく， 機能を相互に分担, 補強できる非均質的な棈造制御が 望まれる、本研究では， $\mathrm{Al}_{2} \mathrm{O}_{3}$ と $\mathrm{TiC}-\mathrm{Ni} や \mathrm{Cr}_{3} \mathrm{C}_{2}-\mathrm{Ni}$ な゙の サーメット層を対称的に傾斜組成化することによって， 勒性, 強度, 硬度の同時向上や損傷の自己检知など, $\mathrm{Al}_{2} \mathrm{O}_{3}$ 固有の特性を越える高次機能化を図った。

\section{2 実的方法}

Table 1に示す3種の組成粉末を，外層を $\mathrm{Al}_{2} \mathrm{O}_{3}$, 中間 層を $\mathrm{TiC}-\mathrm{Al}_{2} \mathrm{O}_{3}-\mathrm{Ni}$ しくは $\mathrm{Cr}_{3} \mathrm{C}_{2}-\mathrm{Al}_{2} \mathrm{O}_{3}$, 中心層を $\mathrm{TiC}-\mathrm{Ni}$ $-\mathrm{Mo}_{2} \mathrm{C}$ もしくは $\mathrm{Cr}_{3} \mathrm{C}_{2}-\mathrm{Nikしてそれぞれ} 5$ 層対称的に皘 層し, CIP成形後, ガラス容器にBN粉末を介して封入 した.つづいてFig. 1に示すSHS/HIP装置により， $100 \mathrm{MPa}$ の空素压下，約 $2000^{\circ} \mathrm{C}$ ，数分で焼結した。

SHS/HIPはHIP中にてSHSが起こり, 反応と同時に焼 結が完了するものをいい，本実験では，Si粉末の窒化 燃泋の反圭熱と窒素压によって瞬間焼結するもので, 原料を半溶融状態にすると同時に拡散が進行しないう 
Table 1 Powder compositions of a green body.

\begin{tabular}{|c|c|c|}
\hline Layer & (A) & (B) \\
\hline Outer & $\mathrm{Al}_{2} \mathrm{O}_{3}, \mathrm{MgO}(0.8)$ & $\mathrm{Al}_{2} \mathrm{O}_{3}, \mathrm{MgO}(0.8)$ \\
\hline Intermediate & $\begin{array}{l}\mathrm{TiC}, \mathrm{Al}_{2} \mathrm{O}_{3}(45), \\
\mathrm{Ni}(5)\end{array}$ & $\begin{array}{l}\mathrm{Cr}_{3} \mathrm{C}_{2}, \\
\mathrm{Al}_{2} \mathrm{O}_{3}(37)\end{array}$ \\
\hline Center & $\begin{array}{l}\mathrm{TiC}, \mathrm{Ni}(30), \\
\mathrm{Mo} 2 \mathrm{C}(10)\end{array}$ & $\mathrm{Cr}_{3} \mathrm{C}_{2}, \mathrm{Ni}(25)$ \\
\hline
\end{tabular}

$(w t \%)$

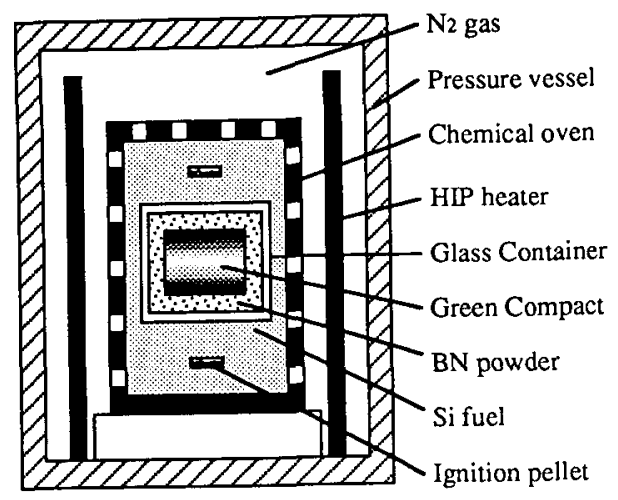

Fig.1 Schematic of SHS/HIP equipment.

ちに緅密化するため，各部で焼結温度が異なる傾斜組 成材料を容易に作製することができる゙．铋源に用いた Siは，亜鉛精練時に残渣として大量に産出したものを 再利用しており，燃焼後は $\beta-\mathrm{Si}_{3} \mathrm{~N}_{4}$ となり耐火物や研磨 剂としてさらに利用することも可能である. 原料成形

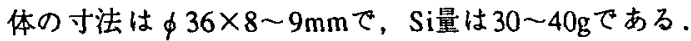

赎結体は，SEM-EDXによる組織観察と組成分析， $\mathrm{Al}_{2} \mathrm{O}_{3}$ 層表面部の $\sin ^{2} \psi-2 \theta$ 法によるX線応力測定 $\left(\mathrm{Al}_{2} \mathrm{O}_{3}\right.$ の ヤング率：400GPa、ボアンン比：0.23とした），1 ンデンテーション法で評洒した局所的な䩗性 ${ }^{2)}$ ，および 3点曲げ強度試験（スパン15mm、層に垂直に荷重を印 加）等で評価した。

\section{3 结果}

\section{1) 構造と組織}

得られた焼結体は， $\phi 30 \times 5 \sim 6 \mathrm{~mm}$ で，十分緻密化 しており体積収縮率は䄪 $40 \%$ であった． Fig.2に $\mathrm{Al}_{2} \mathrm{O}_{3}$ / $\mathrm{TiC} / \mathrm{Ni} / \mathrm{TiC} / \mathrm{Al}_{2} \mathrm{O}_{3}$ 系（以下材料(A)とする）の組成分布を 示す．表面から $1 \mathrm{~mm}$ 程は， $\mathrm{Al}_{2} \mathrm{O}_{3}$ 七ミックスであり， 中心層に行くに従って， TiCおよびNi相が增えていく様 子がかかる. $\mathrm{Ni}_{2} \mathrm{Al}_{2} \mathrm{O}_{3}$ 層に侵入することはなかった。

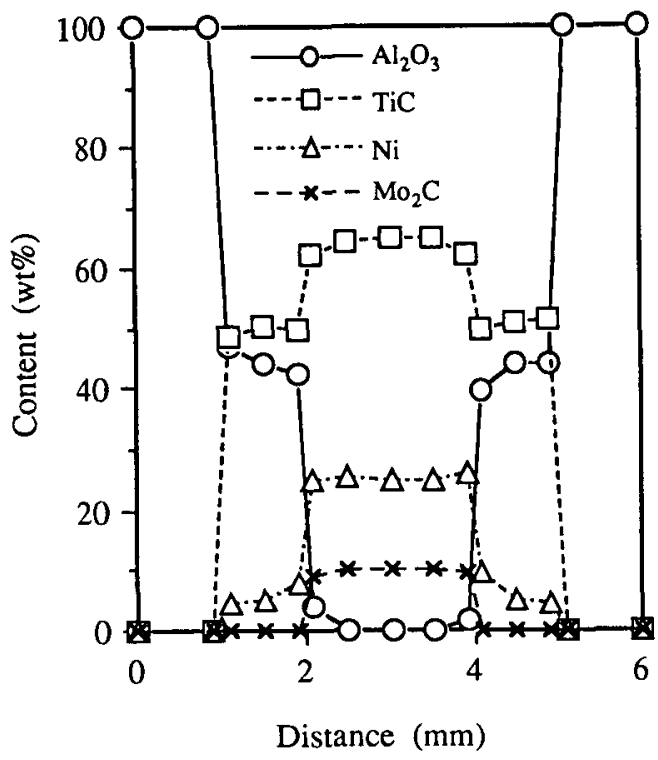

Fig.2 Compositional profiles of the $\mathrm{Al}_{2} \mathrm{O}_{3} / \mathrm{TiC} / \mathrm{Ni} / \mathrm{TiC} /$ $\mathrm{Al}_{2} \mathrm{O}_{3}$ (material (A)).

これは両者の濡れ性が良くないことによるものと考え られる3).

Photo.1に破面組織を示す，(a)は表面 $\mathrm{Al}_{2} \mathrm{O}_{3}$ 層，(b)は $\mathrm{Al}_{2} \mathrm{O}_{3} / \mathrm{TiC}-\mathrm{Al}_{2} \mathrm{O}_{3}$ の界面付近，(c)は TiC- $\mathrm{Al}_{2} \mathrm{O}_{3}$ 層，(d)は $\mathrm{TiC}-\mathrm{Al}_{2} \mathrm{O}_{3} / \mathrm{TiC}-\mathrm{Ni}$ の界面付近，(e)は中心部のTiC-Ni層で ある、いずれも数 $\mu \mathrm{m}$ 以下の微細な粒子で構成されて いるが,一部Niのプールが見られた。また外層では $\mathrm{Al}_{2} \mathrm{O}_{3}$ 粒子の直接結合が, 中間層域では $\mathrm{Al}_{2} \mathrm{O}_{3}$ 同志及び $\mathrm{Al}_{2} \mathrm{O}_{3}$-Tiの直接結合が, 中心層ではTiC-Niの液相焼結に よる粒子結合が支配的であると考えられる，焼結助剂 として添加した $\mathrm{MgO} は \mathrm{Al}_{2} \mathrm{O}_{3}$ 粒子の微細化に，また $\mathrm{Mo}_{2} \mathrm{C}$ は炭素の析出防止と TiCの微細化に威力を発揮しだ?. $\mathrm{Al}_{2} \mathrm{O}_{3} / \mathrm{Cr}_{3} \mathrm{C}_{2} / \mathrm{Ni} / \mathrm{Cr}_{3} \mathrm{C}_{2} / \mathrm{Al}_{2} \mathrm{O}_{3}$ 系（材料(B)）では, Photo.2 に示すように $\mathrm{Cr}_{3} \mathrm{C}_{2}-\mathrm{Ni}$ 層中の $\mathrm{Cr}_{3} \mathrm{C}_{2}$ は柱状に発達した粒 子となった。

\section{2) 機械的特性}

Table 2に，得られた焼結体の機械的特性を示す. 比 较のため，同じ方法で作製した $\mathrm{Al}_{2} \mathrm{O}_{3}$ 焼結体の特性値も あわせて示す. $\mathrm{Al}_{2} \mathrm{O}_{3}$ 七ミックスの䩗性は通常3 $4 \mathrm{MPam}^{1 / 2}$ であるが，それに比べて材料(A)の表面では $6 \mathrm{MPam}^{1 / 2}$ ，(B)では11MPam ${ }^{1 / 2}$ と高い値を示す．Niを 含有する中心部はいずれも15 $\mathrm{MPam}^{1 / 2}$ とインデンテー ション法で評価できる限界に近い高い值となった。 $\mathrm{Al}_{2} \mathrm{O}_{3}$ 表面の硬度も単体 $\mathrm{Al}_{2} \mathrm{O}_{3}$ に比べ，10～20\%高くなっ ているのが認められる．中心部はNiを含むため $11 \mathrm{GPa}$ 


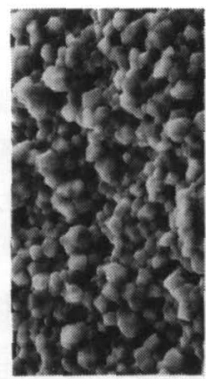

( a )

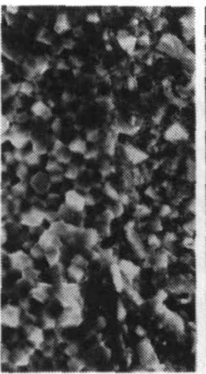

( b )

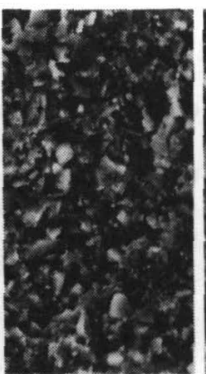

( c )

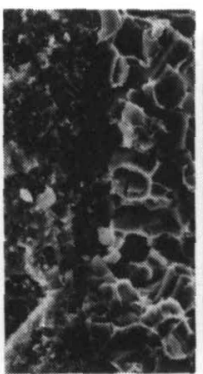

( d )

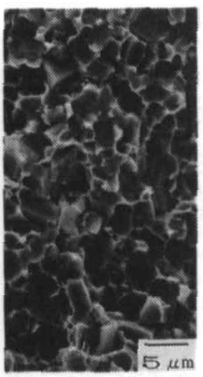

( e )

Photo, 1 SEM image of the fractured surface of the material (A)

(a) outer $\mathrm{Al}_{2} \mathrm{O}_{3}$ layer, (b) interfacial region of $\mathrm{Al}_{2} \mathrm{O}_{3} / \mathrm{TiC}-\mathrm{Al}_{2} \mathrm{O}_{3}$ layers, (c) TiC- $\mathrm{Al}_{2} \mathrm{O}_{3}$ layer,

(d) interfacial region of $\mathrm{TiC}-\mathrm{Al}_{2} \mathrm{O}_{3} / \mathrm{TiC}-\mathrm{Ni}$ layers, (e) center $\mathrm{TiC}-\mathrm{Ni}$ layer.

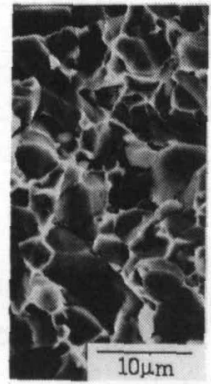

Photo.2 SEM image of the center $\mathrm{Cr}_{3} \mathrm{C}_{2}-\mathrm{Ni}$ layer of the material(B).

Table 2 Mechanical properties of hyperfunctional $\mathrm{Al}_{2} \mathrm{O}_{3}$ ceramics and a monolithic $\mathrm{Al}_{2} \mathrm{O}_{3}$.

\begin{tabular}{|c|c|c|c|c|}
\hline \multicolumn{2}{|c|}{ Sample } & (A) & (B) & \multirow{2}{*}{$\mathrm{Al}_{2} \mathrm{O}_{3}$} \\
\hline \multirow{2}{*}{$\begin{array}{c}\text { Kc }\left(\mathrm{MPam}^{1 / 2}\right) \\
\mathrm{IF}(98 \mathrm{~N})\end{array}$} & surface & 6.0 & 11.0 & \multirow{2}{*}{4.0} \\
\cline { 2 - 4 } & center & 15.0 & 15.0 & \\
\hline \multirow{2}{*}{$\begin{array}{c}\mathrm{Hv}(\mathrm{GPa}) \\
(9.8 \mathrm{~N})\end{array}$} & surface & 20.0 & 22.0 & \multirow{2}{*}{18.0} \\
\cline { 2 - 4 } & center & 11.0 & 9.0 & 400 \\
\hline Flexural strength (MPa) & 900 & 900 & 0 \\
\hline \multicolumn{2}{|c|}{$\begin{array}{c}\text { Residual stress (MPa) } \\
\text { by X-ray analysis }\end{array}$} & -220 & -845 & 0 \\
\hline
\end{tabular}

低くなる，局所的な勒性値や硬度は，Fig.3に例を示す ように，表面から中心部へと傾斜的に変化した，強度 も単体 $\mathrm{Al}_{2} \mathrm{O}_{3}$ に比べると 2〜3倍高い值を示した．材料 (A), (B)とも $\mathrm{Al}_{2} \mathrm{O}_{3}$ 表面にはそれぞれ $220 \mathrm{MPa}, 845 \mathrm{MPa}$ の圧縮応力が認められ，このような大きな残留応力か 材料の強化につながったものと考えられる.

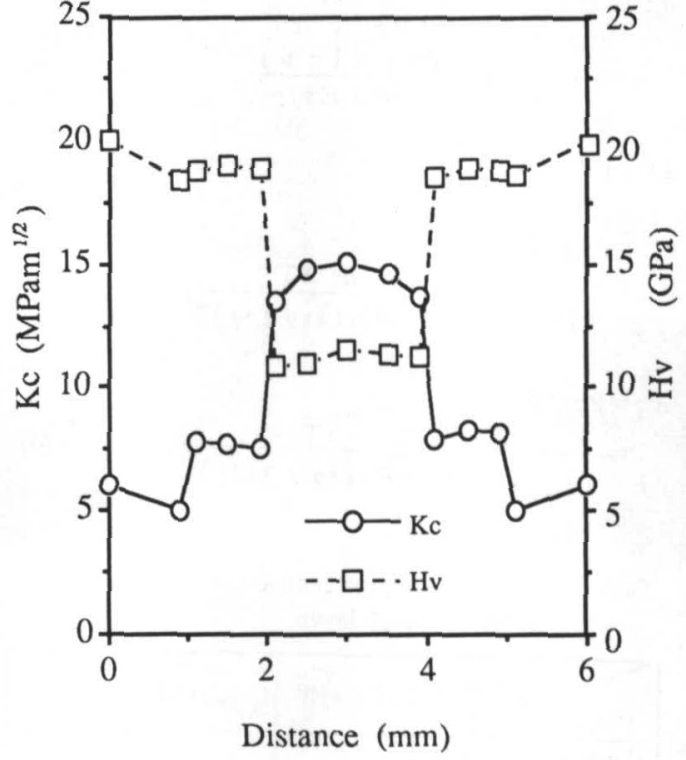

Fig. 3 Profiles of $\mathrm{Kc}$ and $\mathrm{Hv}$ measured on the cross section of the material $(A)$ by indentation technique.

\section{4 考察}

1) 残留応力の推定

対称的に組成傾斜した材料の熱応力を推定するため, Fig. 4 のように外と内で熱膨張率の異なる単純化した 3 層対称構造を仮定し，発生する熱応力をはりの弾性モ デによって計算してみた，すなわち，組成 1 と 2 が 等しく収縮するとする(1)式と，両者にかかる応力が釣 り合ってモーメントがかからないとする(2)式より，そ れぞれに生じる熱応力 $\sigma_{1}, \sigma_{2}$ が (3)，(4) 式で表され る. 但し, ポアンン比はいずれも同じで（ $(\nu=0.23)$, $\Delta \alpha=\alpha_{2}-\alpha_{1}$ とした． Table 3 に計算に使用した各層 


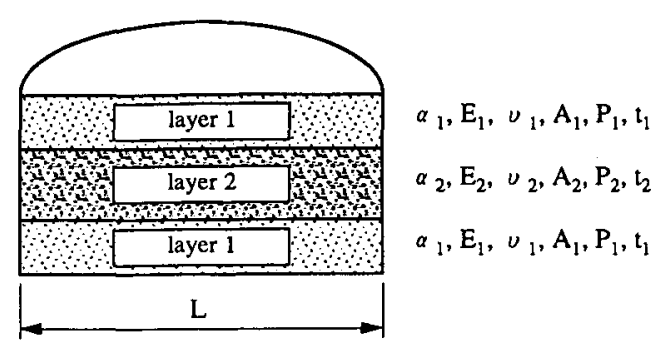

$\alpha$ : thermal expansion coefficient, E: Young's modulus, $v$ : Poison's ratio, A: cross section area, t: thickness of layer, P: force

Fig.4 A trilaminate model for calculation of thermal stress.

$$
\begin{aligned}
& \alpha_{1} \mathrm{~L} \Delta \mathrm{T}+\frac{\mathrm{P}_{1} \mathrm{~L}(1-\nu)}{\mathrm{A}_{1} \mathrm{E}_{1}} \\
& =\alpha_{2} \mathrm{~L} \Delta \mathrm{T}+\frac{\mathrm{P}_{2} \mathrm{~L}(1-\nu)}{\mathrm{A}_{2} \mathrm{E}_{2}}
\end{aligned}
$$

$2 \mathrm{P}_{1}+\mathrm{P}_{2}=0$

$$
\begin{aligned}
\sigma_{1} & =\mathrm{P}_{1} / \mathrm{A}_{1} \\
& =\frac{-\mathrm{E}_{1} \mathrm{E}_{2} \Delta \alpha \Delta \mathrm{T}}{(1-\nu)\left(\mathrm{E}_{2}+2 \mathrm{E}_{1}\left(\mathrm{t}_{1} / \mathrm{t}_{2}\right)\right)}
\end{aligned}
$$

$$
\begin{aligned}
\sigma_{2} & =\mathrm{P}_{2} / \mathrm{A}_{2} \\
& =\frac{\mathrm{E}_{1} \mathrm{E}_{2} \Delta \alpha \Delta \mathrm{T}}{(1-\nu)\left[\mathrm{E}_{1}+\mathrm{E}_{2}\left(\mathrm{t}_{2} / 2 \mathrm{t}_{1}\right)\right]}
\end{aligned}
$$

Table 3 Thermal expansion coefficient and Young's modulus of each layer.

\begin{tabular}{|c|c|c|c|}
\hline Mroperties & $\mathrm{TiC}+\mathrm{Ni}$ & $\mathrm{Cr}_{3} \mathrm{C}_{2}+\mathrm{Ni}$ & $\mathrm{Al}_{2} \mathrm{O}_{3}$ \\
\hline $\begin{array}{c}\text { Thermal expansion } \\
\text { coefficient }\left(1 /^{\circ} \mathrm{C}\right)\end{array}$ & $8.8 \times 10^{-6}$ & $9.9 \times 10^{-6}$ & $8.2 \times 10^{-6}$ \\
\hline $\begin{array}{c}\text { Young's modulus } \\
(\mathrm{GPa})\end{array}$ & 350 & 360 & 400 \\
\hline
\end{tabular}

の熱嘭張率，ヤング率を示す，中心層の熟膨張率は $\mathrm{Al}_{2} \mathrm{O}_{3}$ 層を研削除去して测定した，熟応力が生じる温度 差は， $1000{ }^{\circ} \mathrm{C} に$ 於いて低荷重域では塑性変形を示さな かったことから， $\Delta \mathrm{T}=1000^{\circ} \mathrm{C}$ と仮定した。

その結果, 材料(A)で $\sigma_{1}=-200 \mathrm{MPa}, \sigma_{2}=100 \mathrm{MPa}$ $\left(\mathrm{t}_{1} / \mathrm{t}_{2}=0.25\right), \quad$ (B) $て \sigma_{1}=-650 \mathrm{MPa}, \quad \sigma_{2}=210 \mathrm{MPa}$ $\left(\mathrm{t}_{1} / \mathrm{t}_{2}=0.16\right)$ となった. 雨材料とも計算された $\mathrm{Al}_{2} \mathrm{O}_{3}$ 層の残留応力は実測値と比べやや低くなったことから， 残留応力には熱応力以外に，焼結収縮率差などのプロ セス要因も奇与していることが考えられる，中心層の 引っ張り応力は，外層の厚みを相対的に隇らすことに
よって下げることができる。

2) 残留応力と勒性および強度の関係

$\mathrm{Al}_{2} \mathrm{O}_{3}$ 層表面の鞄性は, 強力な残留応力が存在する状 態で評価したもので， $\mathrm{Al}_{2} \mathrm{O}_{3}$ 固有の勒性ではない.その 限りでは応力に影算された見かけの䩗性になるが、こ の材料を対称的な㑯斜組成棈造と内部応力の分布を有 した一つの機能系と考えると，いわば見かけの勒性が 本性になった材料とみることができよう。このような 非均質材料の諸特性をどう定義し適切に評価するかは 新たな課題であるが、ここに示す䩗性は，線形破壊力 学に基づく従来の方法で評価したもので，いわば実効 的な䩗性といえる，硬度も実效硬度であり，組成変化 と配置による内部応力の分布に影響される。その結果, 外面は $\mathrm{Al}_{2} \mathrm{O}_{3}$ そのものであっても，本来の $\mathrm{Al}_{2} \mathrm{O}_{3}$ とは異 なる、より亶次的な性質や機能を示す。

応力 $\sigma_{\mathrm{R}}$ が残留している試験片に，压子打ち込みに よってメジアン型の琶裂を導入した時の䩚性は次式で 与えられる゙.

$$
\mathrm{Kc}=\mathrm{Kc}^{\circ}-2 \pi^{-1 / 2} \cdot \sigma_{\mathrm{R}} \cdot \mathrm{C}^{1 / 2}
$$

ここで $\mathrm{K} \mathrm{c}^{\circ}$ は $\mathrm{Al}_{2} \mathrm{O}_{3}$ 固有の䩗性，Cは亀裂長さである. Fig. 5 に压子荷重，49，98，196Nで測定した䩗性值と 龟裂長さの関係を示す。

点線は(5)式に $\mathrm{Al}_{2} \mathrm{O}_{3}$ の固有䩗性値 $4 \mathrm{MPam}^{1 / 2}$ とX線応 力測定から求めた応力值を代入したものを示している。

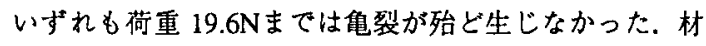
料(A)では，実測したK c と亀裂長さの関係が理論とよ

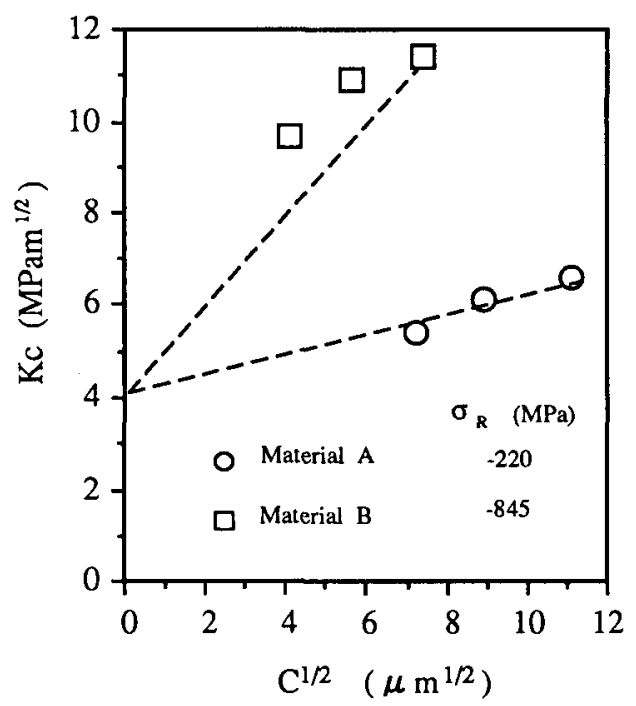

Fig.5 Local toughness at the center of the surface $\mathrm{Al}_{2} \mathrm{O}_{3}$ layer vs crack length $\mathrm{C}^{1 / 2}$. 
く一致しているが，材料(B)では，K cの実測值は(5)式 の関係からずれる。これは残留圧縮応力が $845 \mathrm{MPa}$ 䯩 く，亀裂が測定に用いた压子荷重の範囲でバルムクビ スト型にとどまり，半円形のメジアン型まで発達しな いため，(5)式の関係が成立しないものと考えられる。

図より196N以上の荷重では直線上に乗るものと推測さ れる，いずれにしても，残留圧縮応力が，表面亀裂の 発生を抑制し，実効的な勒性の向上に奇与している結 果を示している。

残留応力 $\sigma_{\mathrm{R}}$ の存在する試験片の引っ張り面中央に圧 子を打ち込んだ時の曲げ強度 $\sigma_{f}$ には次の関係が成り立 $\supset^{6,7)}$.

$$
\sigma_{i}=-\sigma_{\mathrm{R}}+\mathrm{AP}^{-1 / 3}
$$

ここて、A $\mathrm{A}=0.419 \mathrm{Kc}^{4 / 3} \chi^{-1 / 3} ， \chi$ は比例定数，P は 圧子荷重である。.Fig. 6に試料(A)について，強度の圧子 荷重依存性を単体 $\mathrm{Al}_{2} \mathrm{O}_{3}$ のそれとともに示す，材料( $\mathrm{A}$ ) の破断面観察から，19.6N以上の場合，破壊は導入した 初期奄裂から生じているのに対して，P=0や4.9，9.8N の場合は $\mathrm{Al}_{2} \mathrm{O}_{3}$ 層と内層の界面付近から発生しているよ うに思われる， $\mathrm{Al}_{2} \mathrm{O}_{3}$ の場合， $\sigma$ 、は $\mathrm{P}^{-1 / 3}$ に対して原 点近くを通る直線となり，(6)式に抢いて， $\sigma_{\mathrm{R}}=0$ の場

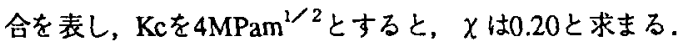
材料(A) 19.6N以上で直線関係を示し，その勾配は $\mathrm{Al}_{2} \mathrm{O}_{3}$ のそれとほほ等しく，Fig.6の $\mathrm{y}$ 切片から求めた $\sigma_{\mathrm{R}}$ はX楾応力测定で得た值に一致した．このことから， 対称的に組成傾斜した材料(A)で残留応力がない場合，

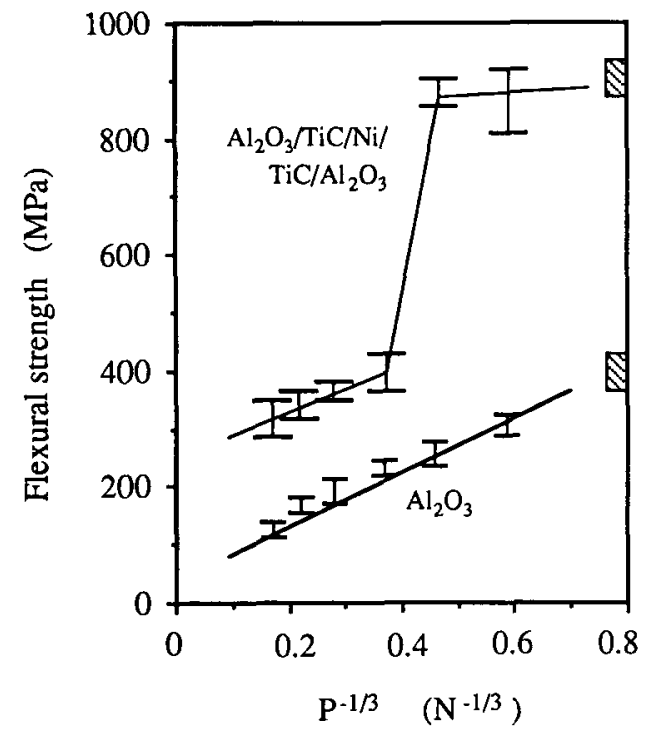

Fig.6 Flexural strength vs indentation load $\mathrm{P}^{-1 / 3}$.
勒性は $\mathrm{Al}_{2} \mathrm{O}_{3}$ のそれとほほ同等である。これらの結果よ ク，材料(A)に19.6N以上で压子を圧入した場合，破堙は 表面加発生し，その特性は $\mathrm{Al}_{2} \mathrm{O}_{3}$ に支配される。 又， 中心層は $\mathrm{Al}_{2} \mathrm{O}_{3}$ 層に圧縮応力を印加する役割を果たすも のの，破壊に対して有効な抵抗となり得ていないこと が分かる。

一方, $\mathrm{P}=9.8 \mathrm{~N}$ 以下の場合, 強度は $19.6 \mathrm{~N}$ 以上に比 較して著しく高く，この差は自然欠陥と残留応力の奇 与だけでは説明できない，そこで，娔結時に界面付近 にNiのプールからなる比較的大きな欠陥が存在したと 仮定すると，曲代荷重を增していった時， $\mathrm{Al}_{2} \mathrm{O}_{3}$ 表面の 小さい欠陥より先に，内部の大きい欠陷から龟裂が成 長する。この場合， $\mathrm{Al}_{2} \mathrm{O}_{3}$ 表面側へ成長した亀裂は 600MPa程度の応力で不安定成長するが，中心層へ向か う龟裂は高い勒性のため安定成長の状態で保持し，材 料全体は破壊せず，さらに荷重を増加した時に破壊に 至る。すなわち，状況によって表面と内部の 2 種類の 欠陷の競合が生じている可能性が考えられる。

よって, 圧子荷重 $9.8 \mathrm{~N}$ 以下で材料(A)の強度が殆ど低 下しないのは，初期亀裂が圧縮応力によって抑制され 自然欠陥の程度にしか成長せず，P=0と同じく破壊の 起源と成り得ないことによるものと考えられる。この 材料をSHS/HIPが終わった後，そのまま同HIP中で1150 ${ }^{\circ} \mathrm{C} ， 30$ 分保持寸ると，無荷重の強度は $1200 \mathrm{MPa}$ に上昇 した.このアニールによって，残留応力が約10\%减少す ることから， $\mathrm{Al}_{2} \mathrm{O}_{3}$ 層と内層との界面近傍の引張り応力 場が多少楥和することや，粒子同士の結合がより強固 になることが考えられる。このように，圧縮応力を有 する傾斜材料は $\mathrm{Al}_{2} \mathrm{O}_{3}$ 層表面に少々の損傷が生じても破 塆には至らず，表面損傷に不敏感な強度の高次機能を もたらすことができる。

Virkar，Catlerらは，AlN-SiC固溶系やZ $\mathrm{ZO}_{2}$ 系で，組成 の異なるセラミックス同士を対称的に三層積層した材 料を作製し，表面セラミックスの欠損許容的な性質を 報告している6 8)。 セラミックスと金属を対称的に傾 斜組成化することで，より強化した材料にすることが できる．材料 (A)，(B)が比較的高い曲げ強度を呈する のは，中心部のサーメット層によるものである。ちな みに $\mathrm{TiC}+30 \mathrm{wt} \% \mathrm{Ni}+10 \mathrm{wt} \% \mathrm{Mo}_{2} \mathrm{C}$ の均一椱合材では $1700 \mathrm{MPa}$ の強度を示した。

細長く加エした曲け試験片 $(2 \times 6 \times 23 \mathrm{~mm})$ の引っ張 ク面中央に圧子荷重を打ち込んだ時，Photo. 3 に見ら れるように筴が長手方向に進展するが，短手方向に 


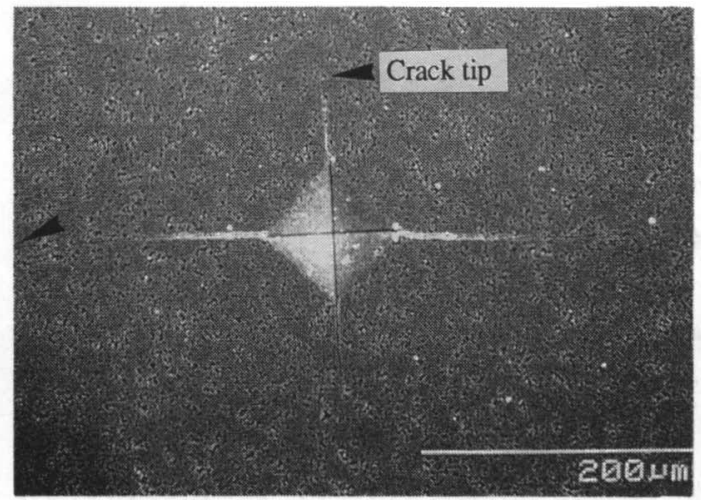

Photo.3 Anisotropic crack propagation at the $\mathrm{Al}_{2} \mathrm{O}_{3}$ surface of a bar specimen cut from the material (A).

は進展しにくい異方性が観察された。これは試料を矩 形に切断したことによって残留応力に異方性が生じた ためで，竹のように縦には亀裂が走るが横には入りに くいユニークな龟裂進展の異方性が見られた。

\section{3) 亀裂の自己検知}

組成を対称的に傾斜配置することで，材料内部に圧 縮/引っ張り/圧縮の応力がバランスした状態が出現 する.この場合，もし表面に亀裂が入り局所的に応力 が開放されると，それが軎面に歪変化となって転写さ れることが考えられる. Fig.7に示すように，材料(A)の $\mathrm{Al}_{2} \mathrm{O}_{3}$ 層表面にダイヤモンドカッターで, 巾と梁さが $0.5 \mathrm{~mm}$ の切り込みを入れる前後で, 軎面の応力変化を 測定した．その結果, 切り込みに直角方向では数十 $\mathrm{MPa}$ の応力減少が見られたが, 切り込みに沿う方向で

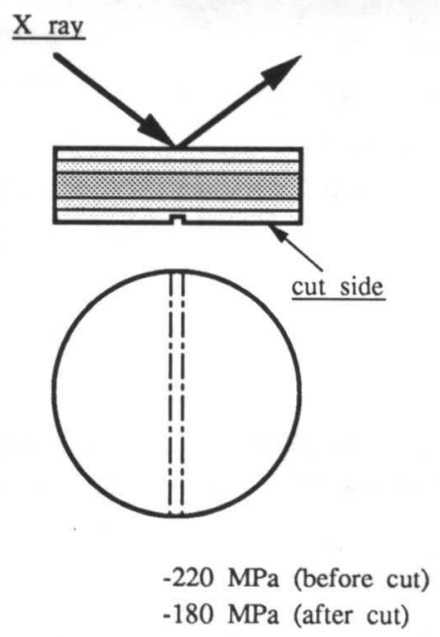

Fig. 7 Schematic of $x$-ray stress measurement at the back side of the material (A), after introducing a cut line on the opposite surface.
は顕著な変化は見られなかった。また切り込みを2本に 増すと応力はさらに減少した。このような現象を利用 し，軎面に歪センサーをとりつけておくと，表面での 損傷の大きさや方向が検知できるインテリジェント機 能も期待できよう9?.

\section{5 站言}

セラミックスと金属を対称的に傾斜組成化した $\mathrm{Al}_{2} \mathrm{O}_{3} / \mathrm{TiC} / \mathrm{Ni} / \mathrm{TiC} / \mathrm{Al}_{2} \mathrm{O}_{3}$ 少 よび $\mathrm{Al}_{2} \mathrm{O}_{3} / \mathrm{Cr}_{3} \mathrm{C}_{2} / \mathrm{Ni} / \mathrm{Cr}_{3} \mathrm{C}_{2} / \mathrm{Al}_{2} \mathrm{O}_{3}$ 系焼結体をSHS/HIPによって作製し，その構造と機能の 関係を調べた，得られた結果を以下に要約する.

1) SHS/HIPはセラミックス/金属組成が対称的に傾斜 化した構造を持つような非均質材料の作製に有効で, かつ亜鉛精練時の残渣 $\mathrm{Si}$ 熱源に再利用し, 燃焼後 も $\mathrm{Si}_{3} \mathrm{~N}_{4}$ として利用できるリサイクルプロセスとして 有望である.

2) 外層の $\mathrm{Al}_{2} \mathrm{O}_{3}$ 層と内層のサーメット層の熱膨張率差や 焼結収縮率差に起因して，数百MPaの残留圧縮応力 が $\mathrm{Al}_{2} \mathrm{O}_{3}$ 層に生じ, $\mathrm{Al}_{2} \mathrm{O}_{3}$ の勒性や硬度を実質的に高 め, 亀裂発生を抑制する機能をもたらした。

3）内層のサーメット層によって高い強度を有した。

4) 圧縮／引張／圧縮の内部応力のバランスの変化を通 じ，表面亀裂を亭面で検知できる可能性が示された。

5）対称的な傾斜組成構造にすることによって材料固有 の特性を越える多様な高次機能が確認された.

\section{文献}

1) Y. Miyamoto, K. Tanihata, T. Kawai and K. Nishida: Proc. Int. Conf. on Hot Isostatic Pressing '93, Antwerp, (1994) 275

2) K. Niihara, R. Morena and D. P. H. Hasselman: J. Am. Ceram. Soc. 65 (1982) C116.

3) J. E. Mcdonald and J. G. Eberhart: Trans. Metal Soc. AIME, 233 (1965) 512

4) 鈴木, 林, 松原: 日本金属学会会報, 22(1983)312

5) D. B. Marshall and B. R. Lawn: J. Am. Ceram. Soc, 60 (1977) 86 .

6) R. Sathyamoorthy, A. V. Virkar and R. A. Cutler: J.Am. Ceram. Soc, 75 (1992) 1136.

7) D. B. Marshall, B. R. Lawn and P. Chantikul: J. Mat. Sci. 14, (1979) 2225 .

8) J. J. Hansen, R. A. Cutler, D. N. Shetty and A. V.Virkar: J. Am. Ceram. Soc, 75 (1992) 1136.

9) Y. Miyamoto, K. Tanihata, Z. Li, Y. S. Kang and A. Murakawa: Proc. 8th CIMTEC Conf. Florence, 1994, in printing . 